\title{
Astrovirus associated gastroenteritis in a children's ward
}

\author{
J. B. KURTZ, T. W. LEE, AND D. PICKERING \\ From the Virology and Public Health Laboratory, Churchill Hospital, Oxford and the \\ Department of Paediatrics, Radcliffe Infirmary, Oxford, England
}

SUMMARY During an outbreak of gastroenteritis in a paediatric ward astroviruses were found in faeces from 17 of 27 symptomatic children and from four of 14 members of the staff with diarrhoea. No viruses were found in 10 asymptomatic children. Fourteen of the 21 astrovirus excretors were free of any recognised pathogens, but in the other seven, rotaviruses or pathogenic bacteria were also present. Serological evidence of astrovirus infection was obtained in five adults and two children.

Over the past few years viruses have been recognised as aetiological agents in many cases of infantile gastroenteritis. A causative role for rotaviruses (Davidson et al., 1975) has been firmly established in many countries. From outbreaks of winter vomiting disease in the USA the Norwalk agent (Dolin et al., 1971), and in Britain the W agent (Clarke et al., 1972), have both transmitted infection to volunteers. Another virus which has been associated with a few cases of gastroenteritis (Appleton and Higgins, 1975; Madeley and Cosgrove, 1975a) has been called an 'astrovirus' because of its star-like appearance in the electron microscope (Madeley and Cosgrove, 1975b). We report here a small outbreak of astrovirus associated gastroenteritis in a children's ward during the winter of 1975-76.

\section{Patients and methods}

During the period December 1975-March 1976, 415 children were admitted to the paediatric ward. Faecal specimens were obtained from 27 of these who had diarrhoea and from 10 asymptomatic children.

Faeces were also provided by 14 of the 18 ward staff members who reported an episode of diarrhoea during this period. To monitor the concurrent situation outside the hospital, faecal specimens from 18 children in the community who had 'loose stools' were examined. These had been randomly selected from those sent to the Public Health Laboratory by general practitioners.

Specimens of serum were obtained from the 18

Received for publication 16 March 1977 members of staff and a few of the children. Paired sera from two volunteers who had been infected with the $\mathrm{W}$ agent were kindly provided by $\mathrm{Dr} \mathrm{S}$. E. Reed, Clinical Research Centre, Salisbury, Wiltshire.

EXAMINATION FOR MICROORGANISMS

All faecal specimens were examined for bacterial pathogens by conventional methods. For examination by electron microscopy (EM) a 10-20\% suspension of faeces was made in phosphate buffered saline (PBS) and centrifuged at $3000 \mathrm{rpm}$ for 30 minutes. The supernatant was then centrifuged at $40000 \mathrm{rpm}(160000 \mathrm{~g})$ for two hours. The pellet thus obtained was suspended in a few drops of glass distilled water and applied to formvar/carbon coated grids. The preparations were negatively stained with $3 \%$ phosphotungstic acid ( $\mathrm{pH} \mathrm{6.0)}$ and examined in a Phillips 301 electron microscope.

For virus isolation the faecal supernatants were inoculated onto cell cultures of monkey kidney, human amnion, and human embryo kidney. These were observed twice weekly for two weeks for cytopathic effect and the cell culture fluids were examined for viruses by EM.

TESTS FOR ANTIBODIES

Antibodies against astroviruses were detected by immune-electron microscopy. A crude virus suspension prepared as above from a specimen of faeces $\mathbb{\infty}$ known to contain large quantities of astrovirus was centrifuged at $\mathbf{4 0} 000 \mathrm{rpm}$ for two hours through $15 \%$ sucrose and washed once in PBS to produce a clean virus suspension. This was diluted so that $0.1 \frac{\rho}{\mathbb{D}}$ $\mathrm{ml}$ of the suspension, as used in the test below, gave $\triangle$ approximately $20-50$ discrete virus particles per $\sigma$ 
electron microscope field at a screen magnification of $\times 40000$. The dilute suspension was stored at $-40^{\circ} \mathrm{C}$ until used. Sera were tested at a dilution of $1: 5$ and 1:20. Equal volumes of serum and virus suspension $(0.1 \mathrm{ml})$ were mixed and held for 1-2 hours at room temperature and then overnight at $+4^{\circ} \mathrm{C}$. After this time $3 \mathrm{ml}$ of PBS were added, the preparation was centrifuged, and grids were prepared as above. The grids were coded and examined for virus/antibody complexes which indicated the presence of astrovirus antibodies. Some sera were also examined for IgM antibody after fractionation on sucrose density gradients.

Rotavirus antibodies were demonstrated by the complement fixation test using antigen prepared from a bovine strain, Oslo, kindly supplied by Professor Krech, Institut für medizinische Mikrobiologie, St. Gallen, Switzerland.

\section{Results}

\section{EXAMINATION OF FAECES}

Faecal specimens were obtained from 37 children on the paediatric ward. Gastroenteritis was present in 27 of these (age range 1 month-5 years, median 7 months), but not in the other 10 children (age range 3 months-11 years, median 24 months). Table 1 gives the results of examination of these specimens. Only two of the 27 symptomatic children were harbouring pathogenic bacteria (see Table 1). In this group, however, 11 were excreting astrovirus alone, and in six more, astroviruses were present together with other potential pathogens.

There were two waves of astrovirus associated gastroenteritis, the symptoms of which were typically a watery diarrhoea lasting two to three days and in one-third of the children an episode of vomiting. Three of the 17 children who were excreting astroviruses were admitted with diarrhoea, or developed it shortly thereafter, and they were probably infected in the community. Their admissions did not, however, precede the waves of infection on the ward. The interval between admission and the date of onset of the gastroenteritis exceeded three days in 13 other children, indicating that they had probably acquired this infection while on the ward. It is difficult to be precise about the origin of the illness in the remaining child. He had previously undergone a panprotocolectomy for ulcerative colitis and had a five-day history of diarrhoea when admitted, but he had attended the outpatient department shortly before the onset of his diarrhoea which possibly was acquired there.

Serial specimens of faeces were available from two infants who were infected with astroviruses. One, whose first specimen taken on the fourth day of illness contained astroviruses (Figure), was still excreting them one week later. The second child was excreting virus on the third and twelfth days, but in a third specimen taken on the nineteenth day no virus was seen.

Rotaviruses alone were seen in the faeces of five children. Two of these were admitted with gastroenteritis and three were infected while on the ward. No microbiological cause could be found for the diarrhoea in the other five children, although Echovirus type 30 was isolated from one of them. Neither were any bacteria or viruses of recognised pathogenicity seen or cultured from the faeces of the 10 children not suffering from diarrhoea.

Eighteen members of staff working on the children's ward during the outbreak reported that they had suffered from diarrhoea, and faeces were available from 14 of these during their illness. No bacterial pathogens were found, but viruses were seen in specimens from five of them. Three contained astroviruses alone, another was excreting both astro and rotaviruses, and one rotaviruses only.

Faeces from 18 children with diarrhoea outside hospital were examined to compare the situation in

Table 1 Viruses found in faeces of 37 children on the ward

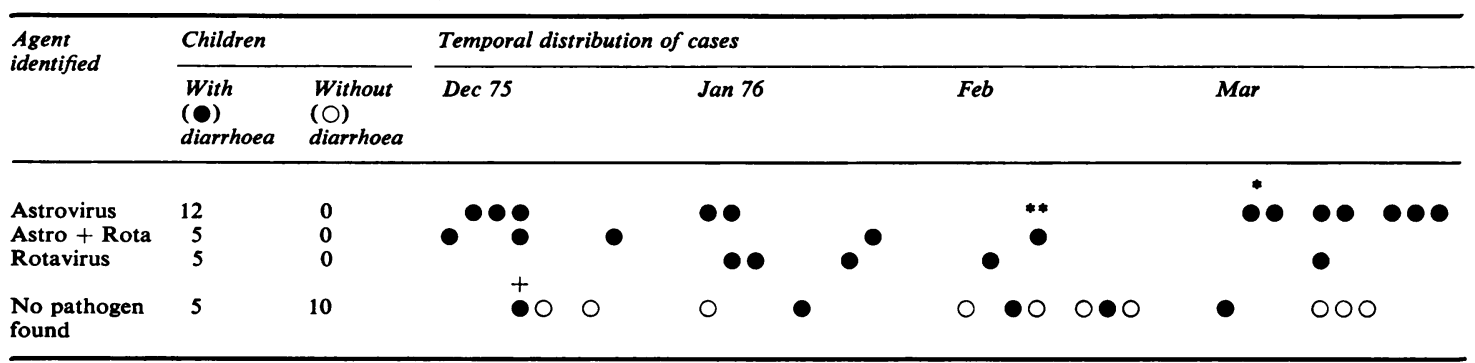

+Echo 30 isolated.

* Salmonella bredeney also isolated.

$* E$. coli $0 \mathrm{I} 28$ also isolated. 


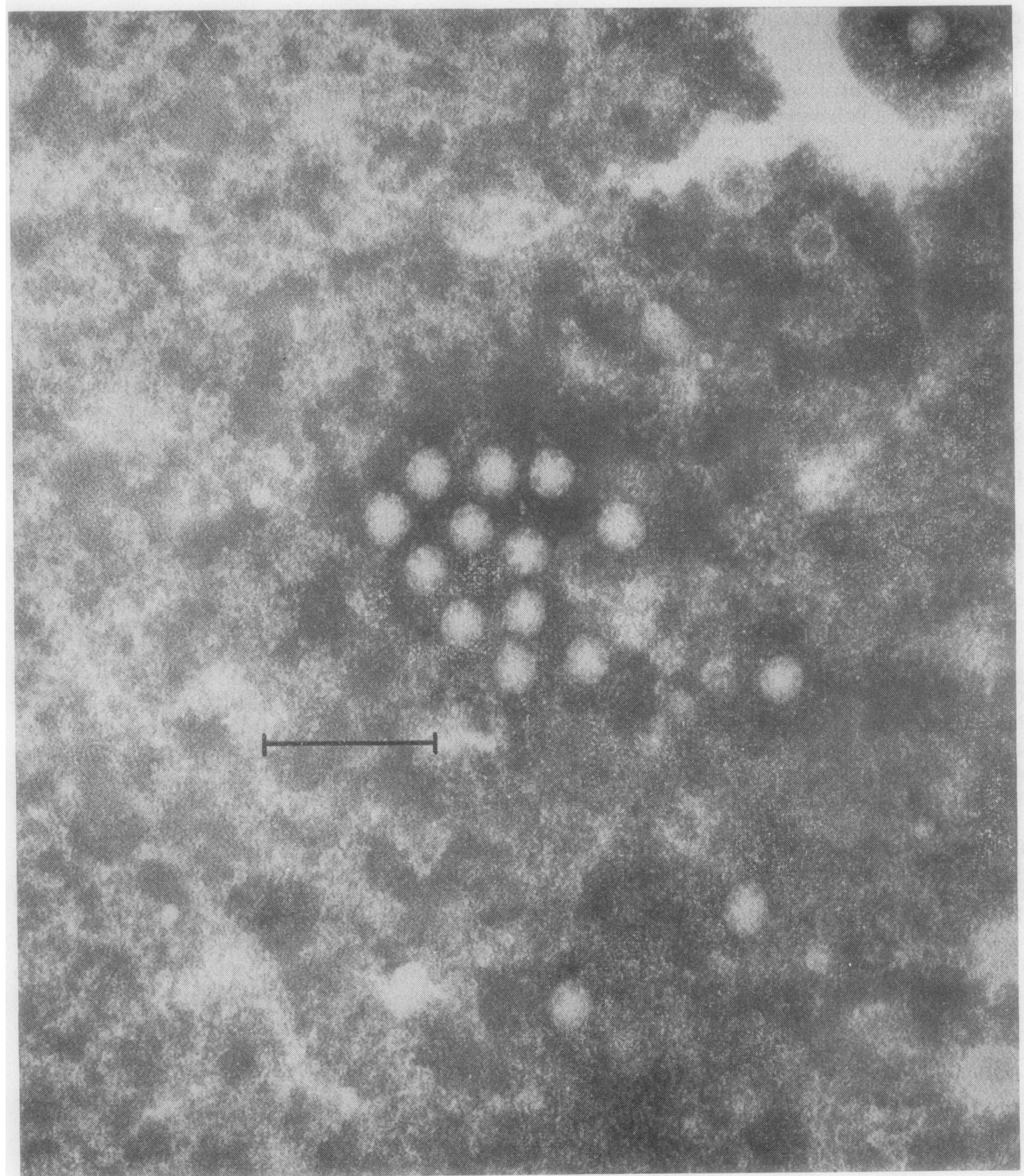

Figure Astroviruses from a child's stool. The bar represents $100 \mathrm{~nm} \times 256000$.

the community with that on the ward, and one was found to be excreting Shigella sonnei. Astroviruses alone were present in two children (aged 14 months and 6 years) and rotaviruses in a 3-year-old child. Adenoviruses were seen but not cultured from a fifth infant.
SEROLOGICAL TESTS

Sera were available from eight people, staff and $\stackrel{D}{\mathbb{D}}$ children, in whose faeces astroviruses and/or rota- $\underset{\mathbb{D}}{\overparen{D}}$ viruses had been seen during their illness. Their anti- $\frac{\varrho}{2}$ body responses are shown in Table 2 . All those infected with the astrovirus had antibody in their 8 
Table 2 Serum antibody responses in patients whose faeces contained viruses

\begin{tabular}{|c|c|c|c|c|c|c|c|c|}
\hline & \multicolumn{8}{|l|}{ Case } \\
\hline & 1 & 2 & 3 & 4 & 5 & 6 & 7 & 8 \\
\hline $\begin{array}{l}\text { Age } \\
\text { Virus present }\end{array}$ & $\begin{array}{l}2 \mathrm{mth} \\
\text { Astro }\end{array}$ & $\begin{array}{l}2 \mathrm{mth} \\
\text { Astro }\end{array}$ & $\begin{array}{l}19 \mathrm{yr} \\
\text { Astro }\end{array}$ & $\begin{array}{l}20 \mathrm{yr} \\
\text { Astro }\end{array}$ & $\begin{array}{l}20 \mathrm{yr} \\
\text { Astro }\end{array}$ & $\begin{array}{l}14 \text { mth } \\
\text { Astro }\end{array}$ & $\begin{array}{l}20 \mathrm{yr} \\
\text { Rota }\end{array}$ & $\begin{array}{l}19 \mathrm{yr} \\
\text { Astro } \\
+ \\
\text { Rota }\end{array}$ \\
\hline $\begin{array}{r}\text { Acute } \\
\text { Astrovirus antibody titre }\end{array}$ & $<5$ & $<5$ & 5 & $<5$ & NA & NA & NA & $<5$ \\
\hline Conv. & 20 & 20 & 5 & 20 & 20 & 20 & $<5$ & 5 \\
\hline $\begin{array}{r}\text { Acute } \\
\text { Rotavirus antibody titre }\end{array}$ & 8 & 8 & $<8$ & 16 & NA & NA & NA & 8 \\
\hline Conv. & 8 & 8 & $<8$ & 16 & 8 & $<8$ & 256 & 256 \\
\hline
\end{tabular}

NA-not available

convalescent sera, and in three cases a rising titre was observed. Sera from patients 4 and 5 were fractionated on sucrose gradients and both had astrovirus antibody in the IgM fraction. Infection with rotaviruses resulted in a high antibody titre to the bovine rotavirus antigen. Patient 8 , who had a dual infection, developed antibodies to both viruses.

Tests on paired sera from five other adults in whose faeces no viruses had been seen showed that one had produced antibodies to the astrovirus, but none was detected in the other four. Antibody against rotavirus was present in low unchanging titres in three of the pairs and absent in the other two. Single convalescent sera were also tested from a further eight adults whose faeces had not been available for testing or had not contained viruses. Astrovirus antibody was present in five of the eight, and one of these had IgM antibody. Thus serological evidence indicated that two people in whose faeces no viruses were seen had recently been infected with astroviruses.

Astrovirus antibodies were not found in the convalescent sera from the two volunteers who had had symptomatic infections after being fed the $\mathrm{W}$ agent.

\section{Discussion}

We have demonstrated an association between astroviruses and gastroenteritis in both adults and children. At the time of the illness, the virus was found in the faeces of 16 people, in whom no other pathogens could be found; moreover, sera were obtained from four of these and all showed an antibody response to the astrovirus infection. Serological evidence suggests that two other adult sufferers, in whose faeces no virus has been seen, had also recently been infected. In seven more cases, astroviruses were found accompanied by potential pathogens, rotaviruses in six and Escherichia coli type 0128 in the other.
There was a clinical impression that the associated gastroenteritis was generally milder than that caused by rotaviruses. Unlike Madeley and Cosgrove (1975a), who found astroviruses in several asymptomatic infants in a nursery outbreak of gastroenteritis, we found no symptom free excretors. In this study, however, we examined only specimens from 10 asymptomatic children, and the median age of this group was considerably higher than that of the ill group.

An indication that astroviruses were circulating in the community during the same period came from finding them in the faeces of two of the 18 children with 'loose stools' seen in general practice. Rotaviruses were also present in the community, and the build-up of both viruses in the paediatric ward testifies to the difficulty of controlling cross infection in such an environment.

The lack of astrovirus antibodies in volunteers after infection with the $\mathrm{W}$ agent suggests that astroviruses are unrelated to either that or the antigenically similar Ditchling agent which was recently implicated in an outbreak of winter vomiting disease (Appleton et al., 1977). Astroviruses should be added to the list of viral agents capable of causing gastroenteritis.

\section{References}

Appleton, H., Buckley, M., Thom, B. T., Cotton, J. L., and Henderson, S. (1977). Virus-like particles in winter vomiting disease. Lancet, 1, 409-411.

Appleton, H., and Higgins, P. G. (1975). Viruses and gastroenteritis in infants (Letter). Lancet, 1, 1297.

Clarke, S. K. R., Cook, G. T., Egglestone, S. I., Hall, T. S., Miller, D. L., Reed, S. E., Rubenstein, D., Smith, A. J., and Tyrell, D. A. J. (1972). A virus from epidemic vomiting disease. British Medical Journal, 3, 86-89.

Davidson, G. P., Bishop, R. F., Townley, R. R. W., 
Holmes, I. H., and Ruck, B. J. (1975). Importance of a new virus in acute sporadic enteritis in children. Lancet, 1, 242-246.

Dolin, R., Blacklow, N. R., DuPont, H., Formal, S., Buscho, R. F., Kasel, J. A., Chames, R. P., Hornick, R., and Chanock, R. M. (1971). Transmission of acute infectious nonbacterial gastroenteritis to volunteers by oral administration of stool filtrates. Journal of Infectious Diseases, 123, 307-312.

Madeley, C. R., and Cosgrove, B. P. (1975a). Viruses in infantile gastroenteritis (Letter). Lancet, 2, 124.

Madeley, C. R., and Cosgrove, B. P. (1975b). $28 \mathrm{~nm}$ particles in faeces in infantile gastroenteritis (Letter). Lancet, 2, 451-452. 